Article

\title{
The Influence of Luminaire Photometric Intensity Curve Measurements Quality on Road Lighting Design Parameters
}

\author{
Dariusz Czyżewski ${ }^{1}$ and Irena Fryc ${ }^{2, *}$ (D) \\ 1 Electrical Power Engineering Institute, Electrical Engineering Faculty, Warsaw University of Technology; \\ 00-661 Warsaw, Poland; dariusz.czyzewski@ien.pw.edu.pl \\ 2 Electrical Engineering Faculty, Bialystok University of Technology; 15-351 Bialystok, Poland \\ * Correspondence: i.fryc@pb.edu.pl
}

Received: 30 May 2020; Accepted: 25 June 2020; Published: 28 June 2020

check for updates

\begin{abstract}
This article presents the research on a road lighting design. In this kind of design for a specific type of a roadway, the number and spacing of luminaires are calculated on the basis of luminaire photometric parameters such as intensity curve (LPIC) and luminous flux. The values of these parameters are measured using the luxmeter, i.e., a measuring instrument in which the spectral sensitivity should imitate spectral sensitivity of the human eye $V(\lambda)$. However, the luxmeter's spectral sensitivity $S(\lambda)$ is not perfectly matched with the required one and varies for different instruments, resulting in measurement errors. To avoid this measurement error, the spectral mismatch correction factor (SMCF) should be applied to luxmeter's readings. For a given luxmeter, the SMCF values depend on the measured light's spectral composition SPD (described also by the lamp's correlated color temperature CCT). Unfortunately, many laboratories do not apply SMCF to their luxmeter readings. Typical measurement laboratories are not in possession of SMCF data as this kind of data is hard to obtain and can be provided only by the state-of-the-art photometric laboratories for a high cost. Consequently, these typical measurement laboratories provide inaccurate LPIC data to costumers. In this article, it has been shown that a design process of road lighting installations needs to be based on lighting fixture LPIC's measurements with SMCF values being taken into account. Omitting this fact may result in road lighting installation made on the basis of a design utilizing incorrect LPIC data, which would have higher energy consumption then expected at a design stage.
\end{abstract}

Keywords: street lighting; luminaire photometric intensity curve; luxmeter; energy efficiency

\section{Introduction}

Modern lighting and lighting of outdoor areas are rapidly growing segments of the lighting market. Illuminated cities (Figure 1a) are places of nighttime human activity. The basic factors influencing the quality of lighting include: luminance level (Figure 1b) and its uniformity (Figure 1c) [1], maintaining an appropriate contrast between the object and the background [2] and limiting glare (to ensure comfortable viewing) [3-5]. Street and road lighting is also intended to ensure pedestrian [6] and road traffic safety [7-9]. The requirements for the lighting - photometric parameters of road lighting are specified in CIE documents (International Commission on Illumination) 115-2010 "Lighting of roads for motor and pedestrian traffic" [10], European standard EN-13201:2015 "Road lighting" [11], as well as in North American standard ANSI/IESNA (American National Standards/Illuminating Engineering Society of North America) RP-8-00 "Roadway Lighting" [12] and in document CIE 150:2017 "Guide on the Limitation of the Effects of Obtrusive Light from Outdoor Lighting Installations" [13]. 


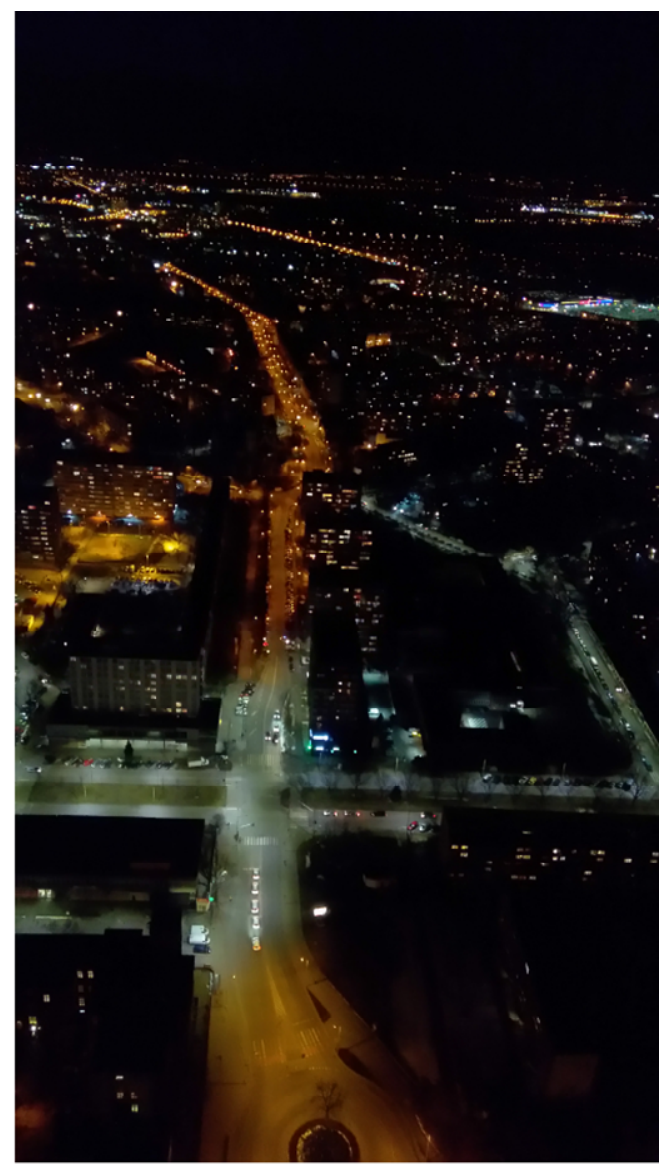

(a)

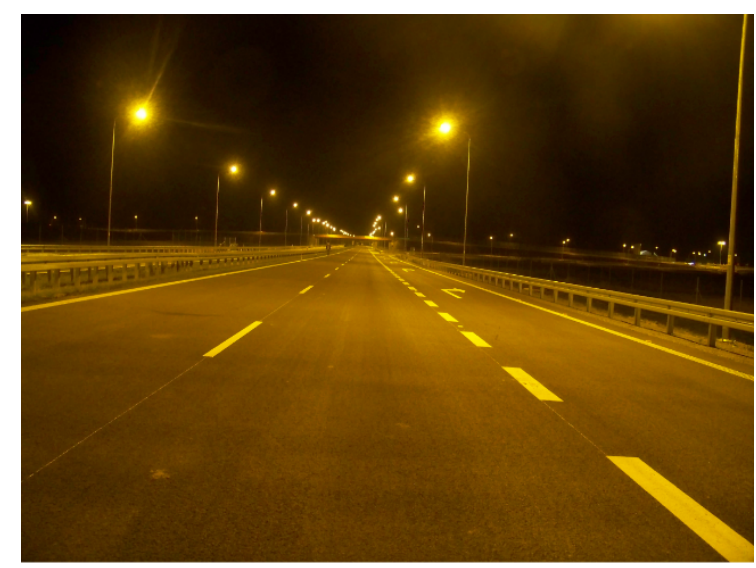

(b)

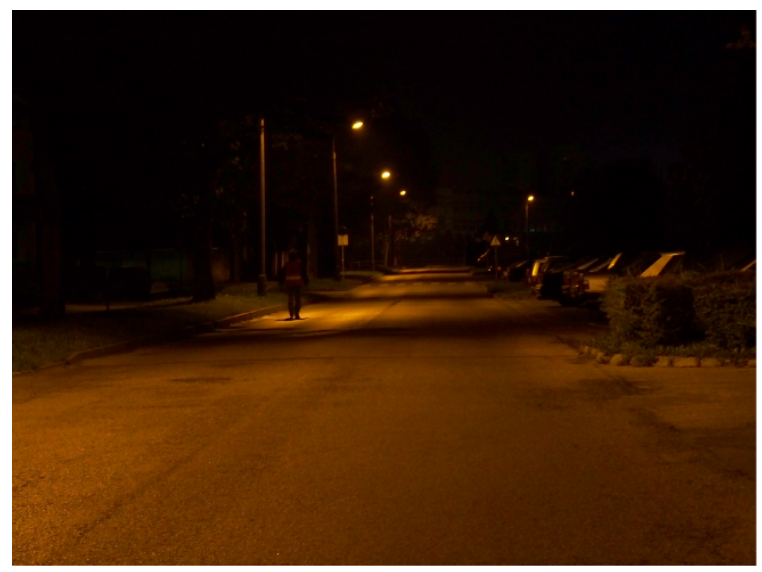

(c)

Figure 1. Pictures of road lighting: (a) roads at Wroclaw city center (Poland) city center, (b) brightness of luminance level of typical road-suburbs in Warsaw (Poland), (c) example of improper road lighting design-luminance nonuniformity at city street of Koszalin (Poland).

In Poland, the costs of operating road lighting place a significant burden on the budgets of the owners (usually municipalities) since as much as $13 \%$ of electricity consumed in Poland [14] is consumed by such installations. This problem is also observed in other European countries [15,16]. Therefore, one of the current priorities set by the European Union and presented in the Green Paper "Lighting the Future, Accelerating the Implementation of Innovative Lighting Technologies" [17], is to reduce electricity consumption for lighting purposes. This document recommends phasing out energy-consuming lamps from outdoor (mainly road) lighting applications. Nowadays, each project of road lighting needs to, apart from qualitative parameters, take also economic criteria into account [18,19] as regards the energy consumption of such an installation [20], e.g., those specified in the European Commission Regulation (EC) No. 245/2009 [21], as well as in the fifth part of the European standard EN-13201:2015 [11].

Due to economic recommendations [22] concerning energy consumption of road lighting installations, virtually all newly designed road investments are illuminated using semiconductor LED light sources $[23,24]$. Additionally, the old -type luminaires such as HPS are being replaced with LED ones on the already existing roads. Typical LED road luminaires are available with a wide range of luminaire photometric intensity curves (LPIC), correlated color temperature (CCT), light flux [lm] and active power P [W]. However, most often in road lighting installations, cold-white LEDs (with 
CCT above $6000 \mathrm{~K}$ ) are used due to their high luminance $[25,26]$ and high luminous efficacy, and thus relatively low power consumption. [27-29].

The quality of the designed lighting installation depends mainly on the photometric parameters of the luminaires used $[30,31]$. Road luminaires are designed to illuminate the road surface properly so that its luminance and its uniformity meet standard requirements [11,32]. Therefore, when designing road lighting, the distribution of the luminaire photometric intensity curve (LPIC) used in a given luminaire design is important $[33,34]$. The luminaire photometric intensity curve (LPIC) is determined in photometric laboratories by using goniophotometric methods, which are based on luxmeter readings [35-38]. The CIE 121:1996 [35] document provides guidance about standard conditions under which luminaires tests should be carried out. This document also describes the possible sources of measurement errors and correction factors. This CIE document was drawn in 1996, i.e., in the days prior to the use of white LEDs in road lighting. That is why it does not directly refer to the accuracy of determining the luminaire photometric intensity curve of LED luminaires. When measuring the LED-based road luminaire photometric intensity curve, we are dealing with a source of measurement error not described in the CIE document 121:1996 [35]. It is the error of measurement resulting from the mismatch between the SPDs (Spectral Power Distribution) of the light source being measured and the SPDs of the standard lamp used to calibrate the luxmeter. When those two of SPDs are different in shape, the luxmeter measurement accuracy depends on SPDs of the measured lamp and is described by parameter $\mathrm{f}_{1}$ (Equation (1)) [39,40].

$$
\mathrm{f}_{1}=\frac{\int_{380}^{780} \mathrm{P}_{\mathrm{S}}(\lambda) \mathrm{S}(\lambda) \mathrm{d} \lambda}{\int_{380}^{780} \mathrm{P}_{\mathrm{S}}(\lambda) \mathrm{V}(\lambda) \mathrm{d} \lambda} \frac{\int_{380}^{780} \mathrm{P}_{\mathrm{A}}(\lambda) \mathrm{V}(\lambda) \mathrm{d} \lambda}{\int_{380}^{780} \mathrm{P}_{\mathrm{A}}(\lambda) \mathrm{S}(\lambda) \mathrm{d} \lambda}-1=\mathrm{SMCF}-1,
$$

where $\operatorname{Ps}(\lambda)$ means relative spectral power distribution (SPD) of the measured light source, $\mathrm{P}_{\mathrm{A}}(\lambda)$ means relative spectral power distribution (SPD) of illuminant A $(C C T=2856 \mathrm{~K})$, i.e, luxmeter calibration source, $V(\lambda)$ is describing relative spectral sensitivity of the human eye and $S(\lambda)$ means relative spectral responsivity of luxmeter, $\mathrm{SMCF}$ is the spectral mismatch correction factor.

Under those conditions, the spectral mismatch correction (SMCF) factor should be applied to luxmeter reading $\left(\mathrm{E}_{\mathrm{r}}\right)$. To get a correct value of lux $(\mathrm{E})$ given by the luxmeter, the lux value must be multiplied by SMCF according to the following formula (2):

$$
\mathrm{E}=\mathrm{SMCF} \cdot \mathrm{E}_{\mathrm{r}}
$$

Unfortunately, many laboratories—especially those without accreditation-do not apply SMCF to their luxmeter readings because they are not in possession of SMCF for all kinds of light source which could be measured by their luxmeters. Those kinds of data are hard to obtain and could be provided only by the state-of-the-art photometric laboratories for a high cost.

Failing to apply the SMCF factor during illuminance measurements influences the measurement inaccuracy significantly [41-44]. It, in turn, translates into inaccuracies in determining luminaire photometric intensity curve (LPIC) data values, which can influence the results of the lighting systems which are designed on the basis of such measurement data.

So far, no scientific paper on how luminaire photometric intensity curve (LPIC) measurements' quality could influence the results of street lighting design has been published. This issue is of a key scientific and practical importance as the design parameters of a given road lighting installation influence the estimated value of electricity consumption, for which minimization is one of the priorities in the operational strategy of the European Union [17].

\section{Materials and Methods}

The studies on how luminaire photometric intensity curve measurements' quality could influence the results of street lighting design were conducted for two typical roadways. For that research, 
among the many possible configurations of the width of the roadway and the number of road lanes, double-line roadways of $7.0 \mathrm{~m}$ and $10.5 \mathrm{~m}$ widths were selected. In such roadways, the luminaires are arranged in a unilateral system (Figure 2), which is very popular in Europe (Figure 2).

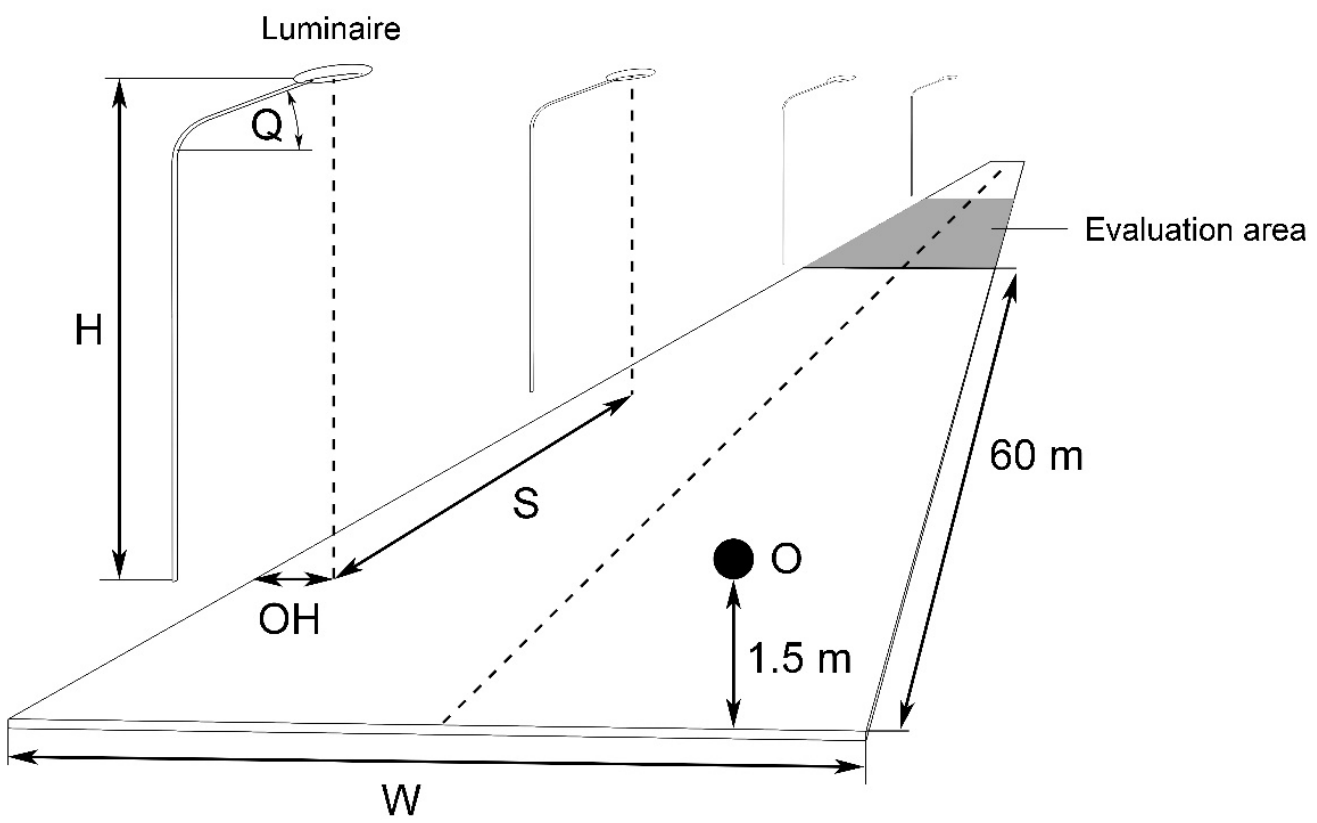

Figure 2. Schematic drawing of the road under consideration, where $\mathrm{H}$-luminaire mounting height; W-width of the roadway; S-distance between lanterns; $\mathrm{OH}$ - overhang; $\mathrm{Q}$ - tilt (angle of the luminaire inclination); $\mathrm{O}-$ observer at $1.5 \mathrm{~m}$ height.

The design of the road lighting installation was done using Dialux Evo 8.2 software (this software is commonly used in Europe for a road lighting design process). This design was carried out to maintain the lighting requirements contained in the standard EN 13201:2015 [11] for road in dry and rain-free conditions, with minimization of the costs of this investment and electricity consumption by it. The project adopted typical lighting classes used for this type of roadway. So, lighting requirements according to M4 lighting class were adopted for a 7.0 meter wide road and lighting requirements according to M2 (Table 1) were adopted for a 10.5 meter wide road. The layout of luminaires for these two types of roads (classes M2 and M4) and their parameters are summarized in Table 2.

Table 1. Requirements of M road lighting classes according to EN 13201:2015 standard.

\begin{tabular}{cccccc}
\hline $\begin{array}{c}\text { Lighting } \\
\text { Classes }\end{array}$ & $\begin{array}{c}\text { Average } \\
\text { luminance } \\
\mathbf{L}_{\mathbf{a v}}\left[\mathbf{c d} / \mathbf{m}^{2}\right] \\
\text { (Minimum } \\
\text { Maintained) }\end{array}$ & $\begin{array}{c}\text { Overall } \\
\text { Uniformity } \\
\mathbf{U}_{\mathbf{o}}[-] \\
\text { (Minimum) }\end{array}$ & $\begin{array}{c}\text { Longitudinal } \\
\text { Uniformity } \\
\mathbf{U}_{\mathbf{i}}[-] \\
\text { (Minimum) }\end{array}$ & $\begin{array}{c}\text { Threshold } \\
\text { Increment } \\
\mathbf{f}_{\mathrm{TI}}[\%] \\
(\text { Maximum) }\end{array}$ & $\begin{array}{c}\text { Edge } \\
\text { Illuminance } \\
\text { Ratio } \\
\mathbf{R}_{\text {EI }}[-] \\
\text { (Minimum) }\end{array}$ \\
\hline M2 & 1.50 & 0.40 & 0.70 & 10 & 0.35 \\
M4 & 0.75 & 0.40 & 0.60 & 15 & 0.30 \\
\hline
\end{tabular}


Table 2. Ranges of luminaire layout geometry parameters.

\begin{tabular}{ccc}
\hline $\begin{array}{c}\text { Geometric Parameters of Luminaire } \\
\text { Settings }\end{array}$ & $\begin{array}{c}\text { Road } \\
\text { M2 Class } \\
(\mathbf{1 0 . 5} \mathbf{~ m})\end{array}$ & $\begin{array}{c}\text { Road } \\
\text { M4 Class } \\
\mathbf{( 7 . 0 ~ m )}\end{array}$ \\
\hline Module (S) & $40 \div 50 \mathrm{~m}$ & $40 \div 50 \mathrm{~m}$ \\
Luminaire mounting height (H) & $9 \div 14 \mathrm{~m}$ & $6 \div 10 \mathrm{~m}$ \\
Overhang (OH) & $0 \div 2.5 \mathrm{~m}$ & $0 \div 2 \mathrm{~m}$ \\
Tilt (Q) & $0^{\circ}$ & $0^{\circ}$ \\
\hline
\end{tabular}

Typical LEDs (exemplary view of the luminaire-Figure 3) of branded manufacturers recognized on the market were used in the design. The service lifetime of these luminaires is L90B10@100000 $\mathrm{h}$ and their other technical parameters are presented in Table 3. The symbols LED_M4 and LED_M2 were used for luminaires for the road at lighting class M4 and M2, respectively. These luminaires are suitable for working with LED that have a correlated color temperature (CCT) of $3000 \mathrm{~K}, 4000 \mathrm{~K}$ or $6500 \mathrm{~K}$. The spectral power distributions (SPDs) of those kind of LEDs are shown in Figure 4 The electrical currents feeding any LED modules (having different CCT) in a given luminaire have been selected in such a way so that this luminaire emits the same value luminous flux (Table 3) regardless of the LED's CCT value.

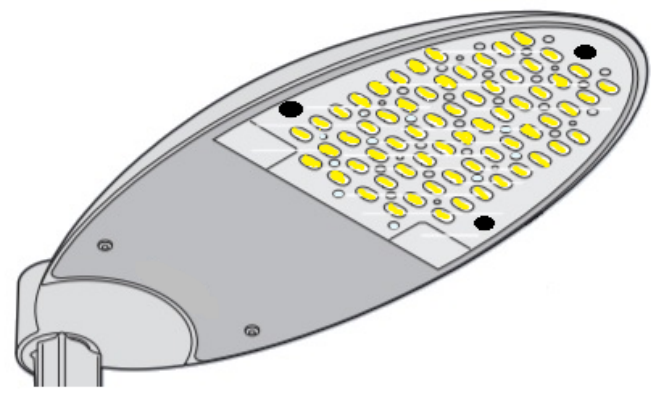

Figure 3. Luminaire layout.

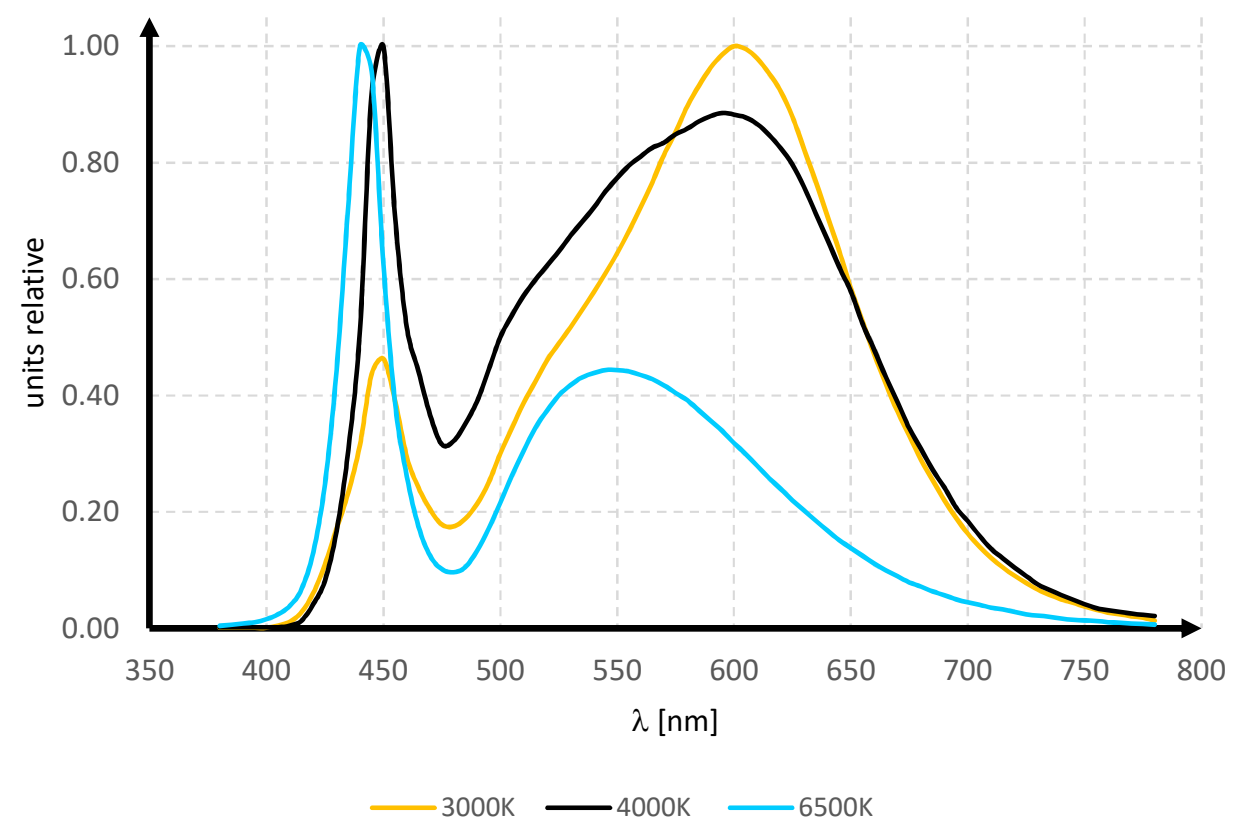

Figure 4. LED spectral distributions with color temperatures: $3000 \mathrm{~K}, 4000 \mathrm{~K}$ and $6500 \mathrm{~K}$. 
Table 3. Basic technical parameters of luminaires selected for M4 and M2 classes.

\begin{tabular}{ccc}
\hline Technical Parameter & $\begin{array}{c}\text { Luminaire for M4 Class } \\
\text { (LED_M4) }\end{array}$ & $\begin{array}{c}\text { Luminaire for M2 Class } \\
\text { (LED_M2) }\end{array}$ \\
\hline Light source type & LED & LED \\
Number of LEDs & 64 & 128 \\
Luminaire luminous flux & $9002[\mathrm{~lm}]$ & $25,571[\mathrm{~lm}]$ \\
Luminaire power & $75[\mathrm{~W}]$ & $195[\mathrm{~W}]$ \\
\hline
\end{tabular}

It was assumed that in the designed road lighting installation, the luminaires would be replaced every 21 years. Therefore, assuming an annual operating time of $4000 \mathrm{~h}$, the Lamp Lumen Maintenance Factor (LLMF) of this installation is 0.92. In accordance with the recommendations of CIE 154:2003 [45] document for average environmental pollution, the cleaning of luminaires at this kind of installation could be carried out every 3 years. This means that the Luminaire Maintenance Factor (LMF) of this lighting installation is 0.87 . Furthermore, it was assumed that the replacement of the luminaires would be total (individual and group) and, therefore, the LSF (Lamp Survival Factor) was 1. As a result, for a designed road lighting installation, the total maintenance factor (MF) was set as 0.8. With those assumptions for both M2 and M4 class roads, an energy-optimized lighting system design was done for luminaires with LEDs of a specific CCT.

Measurements of the luminaire photometric intensity curves (LPIC) were made on a computerized measuring station (Figure 5) used to determine the luminaire photometric intensity curves in the photometric system (C- $\gamma$ ). This station is located in the laboratory of the Department of Light Technology of the Warsaw University of Technology. This laboratory ensures a constant ambient temperature of $25^{\circ} \mathrm{C}$. The specification of the goniophotometer's construction parameters can be found in Table 4.
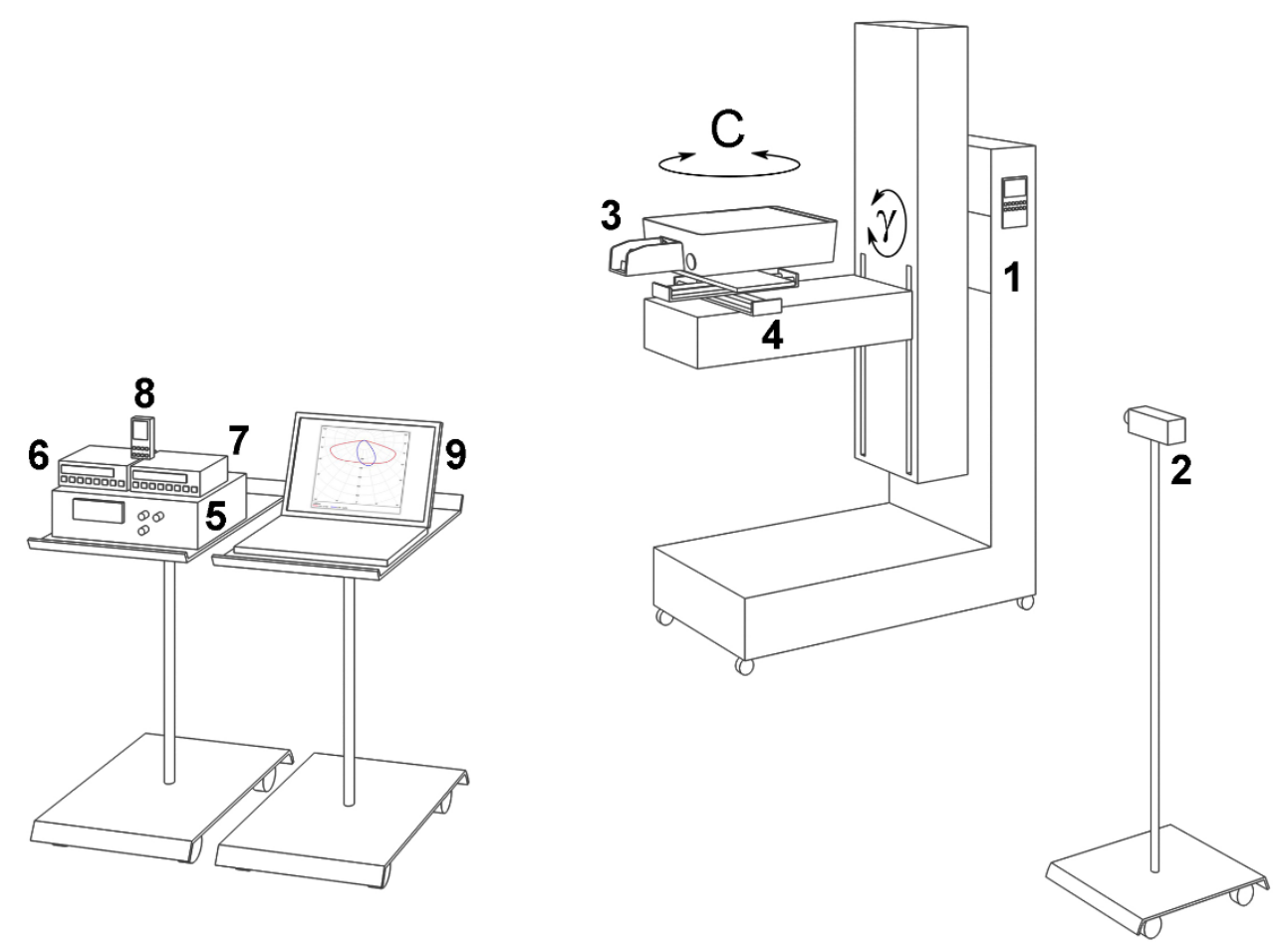

Figure 5. Measurement station where 1-goniophotometer; 2-photometric head; 3-light sources tested; 4-measuring table; 5-power supply with current stabilization; 6,7-laboratory meters; 8-luxmeter; 9-computer. 
Table 4. Warsaw University of Technology goniophotometer specification.

\begin{tabular}{|c|c|}
\hline Parameter & Description \\
\hline Size of measuring object & $\begin{array}{l}<=1200 \mathrm{~mm} \text { diameter of luminous area } \\
<=1220 \mathrm{~mm} \text { mechanical diameter }\end{array}$ \\
\hline Space required & $\mathrm{LxWxH}=2000 \times 1800 \times 400[\mathrm{~mm}]$ \\
\hline Movement & $\begin{array}{l}\text { Illumination meter placed in front of the goniometer on a tripod (the } \\
\text { lamp two independent axes arranged vertically to each other }(C,))\end{array}$ \\
\hline $\begin{array}{l}\text { Measuring position of } \\
\text { the tested object }\end{array}$ & $\begin{array}{l}\text { Normal position, no movement of the tested object. The whole } \\
\text { goniometer can be swiveled which permits different measuring } \\
\text { positions to be set }\end{array}$ \\
\hline Measuring distance & No limit \\
\hline Travel path & $\mathrm{C}=0^{\circ} \ldots 360^{\circ}, \gamma=0^{\circ} \ldots 180^{\circ}$ \\
\hline Positioning accuracy & $\mathrm{C}<0.02^{\circ}, \gamma<0.05^{\circ}$ \\
\hline Repetitive accuracy & $\mathrm{C}<0.01^{\circ}, \gamma<0.02^{\circ}$ \\
\hline Material & Steel and aluminum coated with special black paint \\
\hline Drives and control & Drives and servo amplifier \\
\hline Gears & High precision \\
\hline
\end{tabular}

This station consists of a goniophotometer (1), a luxmeter photometric head (2), the examined light source (3) placed on a measuring table (4). The luminaire was powered by a current-stabilized power supply (5). The compliance with the luminaire manufacturer's recommendations, its current and voltage supply parameters and thermal parameters were controlled by laboratory meters (6) and (7). The readings were made using a luxmeter (8) transferring data to a computer (9).

In this kind of measurement, it is also possible to use a spectroradiometer instead of a luxmeter. It is possible to derive light intensity numerically using SPDs data scaled in $\mathrm{W} / \mathrm{m} 2 / \mathrm{nm}$. However, this method requires the use of highly specialized measuring instruments [46], which are not available in typical photometric laboratories where luminaire's lighting parameters are measured [47]. Only advanced spectroardiometers could ensure high accuracy of light intensity measurements (better than those performed by using the class B luxmeter). They can be sperctroradiometers based on a double monochromator [48-50] (which are expensive, large-size, slow-measuring instruments) or multichannel array spectroradiometers with stray light correction [51,52] (which are not slow but are also expensive). Due to high level of their stray light, relatively cheap and more and more popular compact spectroradiometers do not provide sufficient measurement accuracy when measuring white LEDs [53-55]. Therefore, this kind of instrument should not be used for LPIC measurements of LED luminaires.

The LPIC measurements for a given luminaire were done by four high class B (class $\mathrm{B}$ is old nomenclature according to Standard ISO/CIE 19476:2014, but according to new nomenclature-Technical Report CIE 231:2019—this class is described as class 2), state-of-the-art luxmeters of recognized manufactures, which are typically used in photometric laboratories all over the world. The luxmeters used in the measurements were characterized by the value of $\mathrm{f}_{1}{ }^{\prime}$ parameter equal to $3.16 \%, 5.03 \%, 5.27 \%$ and $5.62 \%$, respectively. The $S(\lambda)$ spectral sensitivity curves of these luxmeters are shown in Figure 6. Figure 7 shows the SMCF values (left) and $f_{1}$ [\%] error (right) of luxmeters under consideration (the numbers given in the description of the figures refer to the value of $\mathrm{f}_{1}{ }^{\prime}$ parameter of the given luxmeter). 


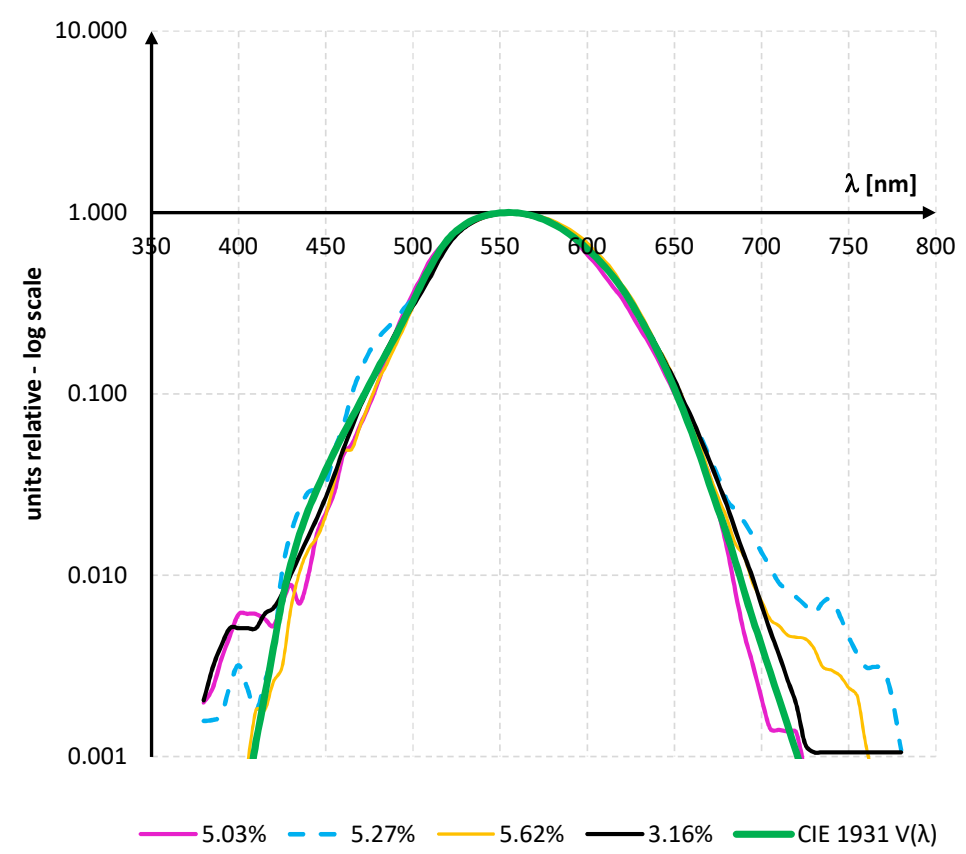

Figure 6. Spectral sensitivity $S(\lambda)$ of the four luxmeters used for measurements and the $V(\lambda)$ curve.

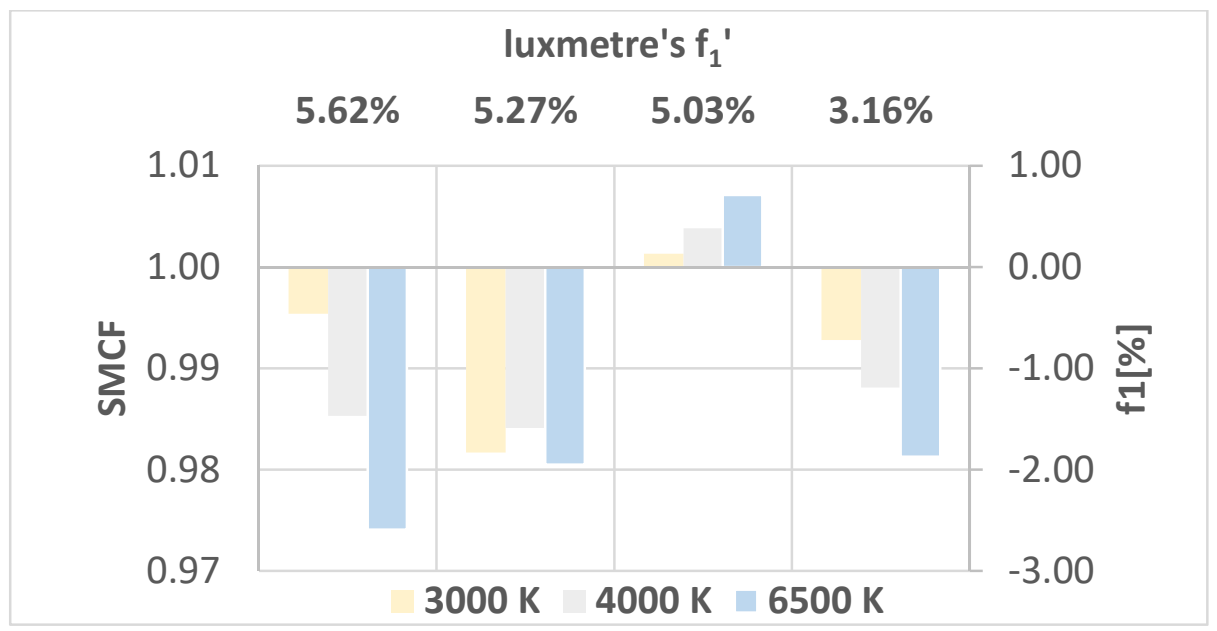

Figure 7. Graphic illustration of changes in $\mathrm{f} 1[\%]$ error value and SMCF correction factors when measured with selected Class B (according to new nomenclature this is class 2 ) luxmeters.

Based on those measurements for each luminaire (three LED_M2 luminaires and three LED_M4 luminaires) equipped with LEDs for a given CCT, we obtained four different photometric intensity curves (LPIC) - each luminaire were photometricized 4 times. Those curves were measured with a given luxmeter, without applying SMCF to its reading data-as it is a common practice of many photometric laboratories, especially those without accreditation $[56,57]$.

The design process was carried out 12 times, i.e., for each of the three luminaires (with CCT values of $3000 \mathrm{~K}, 4000 \mathrm{~K}$ and $6500 \mathrm{~K}$ ) and four results of LPIC measurements obtained using 4 different Class B luxmeters (with $\mathrm{f}_{1}{ }^{\prime}$ values of $3.16 \% ; 5.03 \% ; 5.27 \%$ and $5.62 \%$ ).

In addition, for each type of road, the reference lighting design project was made. These projects were made using LPIC data of a given luminaire working with a light source having specific CCT and when the luxmeter reading was corrected by the SMCF factor. The "reference projects" presented in that paper could be useful (as reference data) for all lighting installation projects (not only for the 12 cases presented in that paper) if design will be based on the same luminaire as were used for that paper. 


\section{Results}

Luminaire photometric intensity curves (LPIC) for plane C0-C180 (blue) and for plane C90-C270 (red), measured with different luxmeters and the reference curve (original, error-free with SMCF applied into luxmeter reading) are shown in Figures 8 and 9. Only some chosen LPIC data are presented in order to ensure legibility of data in Figures 8 and 9 due to the fact that for different LED's CCTs and luxmeter's $\mathrm{f}_{1}{ }^{\prime}$, the character of these curves is similar (the difference occurs only in the intensity values). Figure 8 presents the LPIC for LED_M4 luminaire (working with LED having CCT equal to $6500 \mathrm{~K}$ ) measured by luxmeters having $\mathrm{f}_{1}{ }^{\prime}=3.16 \%$ and $\mathrm{f}_{1}{ }^{\prime}=5.62 \%$. Similar data for the LED_M2 luminaire are shown in Figure 9.

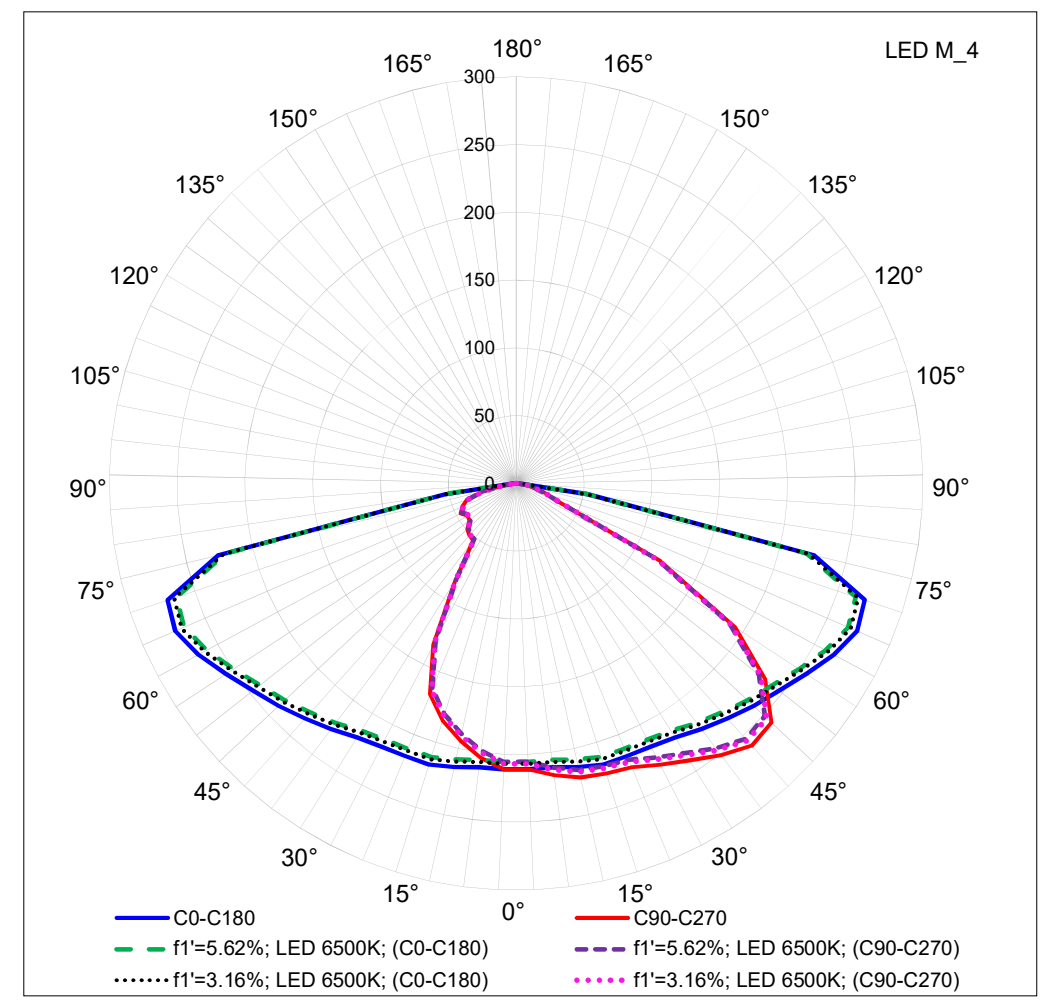

Figure 8. Luminaire photometric intensity curves for LED_M4 luminaire. 


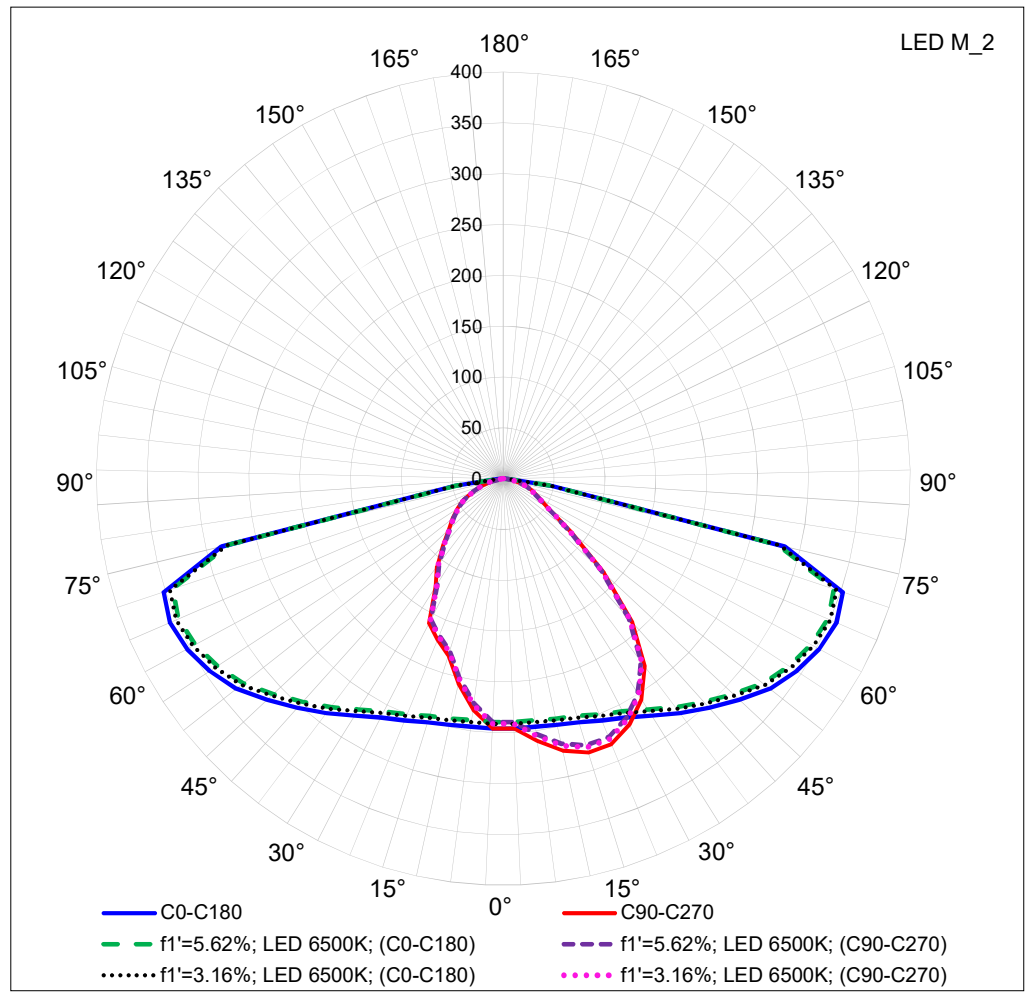

Figure 9. Luminaire photometric intensity curves for LED_M2 luminaire.

A lighting design for the M4 road (7.0-meter width) and M2 road (10.5-meter width) was done with the luminaires characterized by parameters shown in Table 5 . The assumptions of that design process (boundary conditions for the layout of luminaires) are provided in Table 2, where the information about adopted maintenance system and electricity consumption is also given.

Table 5. Luminaire layout geometry parameters-reference designs.

\begin{tabular}{ccc}
\hline $\begin{array}{c}\text { Geometric Parameters of } \\
\text { Luminaire Settings }\end{array}$ & $\begin{array}{c}\text { Road } \\
\text { M2 Class (10.5 m) }\end{array}$ & $\begin{array}{c}\text { Road } \\
\text { M4 Class (7.0) } \mathbf{~}\end{array}$ \\
\hline Module (S) & $49.5 \mathrm{~m}$ & $43.5 \mathrm{~m}$ \\
Luminaire mounting height (H) & $12.5 \mathrm{~m}$ & $8.5 \mathrm{~m}$ \\
Overhang (OH) & $2.5 \mathrm{~m}$ & $1.5 \mathrm{~m}$ \\
Tilt (Q) & $0^{\circ}$ & $0^{\circ}$ \\
\hline
\end{tabular}

The results of the reference lighting design (LPIC measurements were done taking into account the luxmeter SMCF factor) are summarized in Tables 6 and 7. The lighting normative requirements given by the EN-13201:2015 standard for those kinds of roads are also provided in those tables. Table 8 (showing data for the 7.0 meter wide road) and Table 9 (showing the data for the 10.5 meter wide road) contain the results of lighting design made on the basis of LPIC measurements when the SMCF of the luxmeter was not taken into account. The first column shows the CCT of the LED light. The second column shows the geometry of the luminaire layout as: spacing $(\mathrm{S})$ (module) $[\mathrm{m}] /$ luminaire height $(\mathrm{H})$ $[\mathrm{m}] /$ inclination angle $(\mathrm{Q})\left[^{\circ}\right] /$ overhang $(\mathrm{OH})[\mathrm{m}]$. The red color indicates the photometric parameters that do not meet the normative lighting requirements and the energy parameters that have increased (deteriorated) compared to the reference project. 
Table 6. Results of reference photometric calculations for the $7 \mathrm{~m}$ wide road.

\begin{tabular}{cccccc}
\hline & $\begin{array}{c}\text { Average } \\
\text { Luminance } \\
\mathbf{L}_{\mathbf{a v}}\left[\mathbf{c d} / \mathbf{m}^{2}\right] \\
\text { (Minimum } \\
\text { Maintained) }\end{array}$ & $\begin{array}{c}\text { Overall } \\
\text { Uniformity } \\
\mathbf{U}_{\mathbf{0}}[-] \\
\text { (Minimum) }\end{array}$ & $\begin{array}{c}\text { Longitudinal } \\
\text { Uniformity } \\
\mathbf{U}_{1}[-] \\
\text { (Minimum) }\end{array}$ & $\begin{array}{c}\text { Threshold } \\
\text { Increment } \\
\mathbf{F}_{\text {TI }}[\%] \\
\text { (Maximum) }\end{array}$ & $\begin{array}{c}\text { Edge } \\
\text { Illuminance } \\
\text { Ratio } \\
\mathbf{R}_{\text {EI }}[-] \\
\text { (Minimum) }\end{array}$ \\
\hline $\begin{array}{c}\text { Reference } \\
\text { installation } \\
\begin{array}{c}\text { Lighting } \\
\text { requirements }\end{array}\end{array}$ & 0.75 & 0.50 & 0.63 & 13 & 0.58 \\
\hline
\end{tabular}

Table 7. Results of reference photometric calculations for the $10.5 \mathrm{~m}$ wide road.

\begin{tabular}{cccccc}
\hline & $\begin{array}{c}\text { Average } \\
\text { Luminance } \\
\mathbf{L}_{\text {av }}\left[\mathbf{c d} / \mathbf{m}^{2}\right] \\
\text { (Minimum } \\
\text { Maintained) }\end{array}$ & $\begin{array}{c}\text { Overall } \\
\text { Uniformity } \\
\mathbf{U}_{\mathbf{0}}[-] \\
\text { (Minimum) }\end{array}$ & $\begin{array}{c}\text { Longitudinal } \\
\text { Uniformity } \\
\mathbf{U}_{1}[-] \\
\text { (Minimum) }\end{array}$ & $\begin{array}{c}\text { Threshold } \\
\text { Increment } \\
\mathbf{F}_{\text {TI }}[\%] \\
\text { (Maximum) }\end{array}$ & $\begin{array}{c}\text { Edge } \\
\text { Illuminance } \\
\text { Ratio } \\
\mathbf{R}_{\text {EI }}[-] \\
\text { (Minimum) }\end{array}$ \\
\hline $\begin{array}{c}\text { Reference } \\
\text { installation } \\
\text { Lighting } \\
\text { requirements }\end{array}$ & 1.50 & 0.51 & 0.85 & 10 & 0.60 \\
\hline
\end{tabular}

Table 8. Results of design for the $7 \mathrm{~m}$ wide road, based on photometric data properly measured with SMCF correction factor (reference) and without SMCF for 4 different Class B luxmeters.

\begin{tabular}{|c|c|c|c|c|c|c|c|c|c|}
\hline $\begin{array}{l}\text { Case } \\
\text { No. }\end{array}$ & CCT LED & $\begin{array}{l}\text { Geometry } \\
\text { (S/H/Q/OH) }\end{array}$ & $\begin{array}{c}\mathrm{L}_{\mathrm{av}} \\
{[\mathrm{cd} / \mathrm{m} 2]}\end{array}$ & $\begin{array}{l}\mathrm{U}_{\mathbf{o}} \\
{[-]}\end{array}$ & $\begin{array}{l}U_{1} \\
{[-]}\end{array}$ & $\begin{array}{l}\mathrm{F}_{\mathrm{TI}} \\
{[\%]}\end{array}$ & $\begin{array}{c}\mathbf{R}_{\mathrm{EI}} \\
{[-]}\end{array}$ & $\begin{array}{c}\text { De } \\
{\left[\mathrm{kWh} / \mathrm{m}^{2}\right.} \\
\text { year }]\end{array}$ & $\begin{array}{c}\mathrm{Dp} \\
{[\mathrm{mW} /(\mathbf{l x}} \\
\left.\left.\mathrm{m}^{2}\right)\right]\end{array}$ \\
\hline & Reference & $43.5 / 8.5 / 0 / 1.5$ & 0.75 & 0.50 & 0.63 & 13 & 0.58 & 0.985 & 23.8 \\
\hline & \multicolumn{9}{|c|}{ Class B $\left(f_{1^{\prime}}=3.16 \%\right)$} \\
\hline 1 & $3000 \mathrm{~K}$ & $43.5 / 8.5 / 0 / 1.0$ & 0.74 & 0.55 & 0.63 & 13 & 0.64 & 0.985 & 23.6 \\
\hline 2 & $4000 \mathrm{~K}$ & $44.0 / 8.5 / 0 / 1.5$ & 0.74 & 0.50 & 0.62 & 13 & 0.58 & 0.974 & 23.8 \\
\hline \multirow[t]{2}{*}{3} & $6500 \mathrm{~K}$ & $44.5 / 8.5 / 0 / 1.5$ & 0.73 & 0.49 & 0.60 & 13 & 0.58 & 0.963 & 23.8 \\
\hline & \multicolumn{9}{|c|}{ Class B $\left(\mathrm{f}_{1^{\prime}}=5.03 \%\right)$} \\
\hline 4 & $3000 \mathrm{~K}$ & $43.5 / 8.5 / 0 / 1.5$ & 0.75 & 0.50 & 0.63 & 13 & 0.58 & 0.985 & 23.8 \\
\hline 5 & $4000 \mathrm{~K}$ & $43.0 / 8.5 / 0 / 1.0$ & 0.75 & 0.56 & 0.64 & 12 & 0.64 & 0.997 & 23.6 \\
\hline \multirow[t]{2}{*}{6} & $6500 \mathrm{~K}$ & $43.0 / 8.5 / 0 / 1.0$ & 0.75 & 0.56 & 0.64 & 12 & 0.64 & 0.997 & 23.6 \\
\hline & \multicolumn{9}{|c|}{ Class B $\left(\mathrm{f}_{1^{\prime}}=5.27 \%\right)$} \\
\hline 7 & $3000 \mathrm{~K}$ & $44.0 / 8.5 / 0 / 1.0$ & 0.74 & 0.55 & 0.61 & 13 & 0.64 & 0.974 & 23.6 \\
\hline 8 & $4000 \mathrm{~K}$ & $44.0 / 8.5 / 0 / 1.0$ & 0.74 & 0.55 & 0.61 & 13 & 0.64 & 0.974 & 23.6 \\
\hline \multirow[t]{2}{*}{9} & $6500 \mathrm{~K}$ & $44.5 / 8.5 / 0 / 1.5$ & 0.73 & 0.49 & 0.6 & 13 & 0.58 & 0.963 & 23.8 \\
\hline & \multicolumn{9}{|c|}{ Class B $\left(f_{1^{\prime}}=5.62 \%\right)$} \\
\hline 10 & $3000 \mathrm{~K}$ & $43.5 / 8.5 / 0 / 1.0$ & 0.74 & 0.55 & 0.63 & 13 & 0.64 & 0.985 & 23.6 \\
\hline 11 & $4000 \mathrm{~K}$ & $44.0 / 8.5 / 0 / 1.0$ & 0.74 & 0.55 & 0.61 & 13 & 0.64 & 0.974 & 23.6 \\
\hline 12 & $6500 \mathrm{~K}$ & $44.5 / 8.5 / 0 / 1.0$ & 0.73 & 0.55 & 0.60 & 13 & 0.64 & 0.963 & 23.6 \\
\hline
\end{tabular}


Table 9. Results of design for the $10.5 \mathrm{~m}$ wide road, based on photometric data properly measured with correction (reference) and without the correction factor (4 different Class B luxmeters).

\begin{tabular}{|c|c|c|c|c|c|c|c|c|c|}
\hline $\begin{array}{l}\text { Case } \\
\text { No. }\end{array}$ & CCT LED & $\begin{array}{c}\text { Geometry } \\
\text { (S/H/Q/OH) }\end{array}$ & $\begin{array}{c}\text { Lav } \\
{[\mathrm{cd} / \mathrm{m} 2]}\end{array}$ & $\begin{array}{l}\text { Uo } \\
{[-]}\end{array}$ & $\begin{array}{l}\text { U1 } \\
{[-]}\end{array}$ & $\begin{array}{l}\text { FTI } \\
{[\%]}\end{array}$ & $\begin{array}{c}\text { REI } \\
{[-]}\end{array}$ & $\begin{array}{c}\text { De } \\
{\left[\mathrm{kWh} / \mathrm{m}^{2}\right.} \\
\text { year }]\end{array}$ & $\begin{array}{c}\mathrm{Dp} \\
{[\mathrm{mW} /(\mathbf{l x}} \\
\left.\left.\mathrm{m}^{2}\right)\right]\end{array}$ \\
\hline & Reference & $49.5 / 12.5 / 0 / 2.5$ & 1.50 & 0.51 & 0.85 & 10 & 0.60 & 1.50 & 17.3 \\
\hline & & \multicolumn{8}{|c|}{ Class B $\left(f_{1^{\prime}}=3.16 \%\right)$} \\
\hline 1 & $3000 \mathrm{~K}$ & $49.5 / 12.5 / 0 / 2.5$ & 1.51 & 0.51 & 0.85 & 10 & 0.60 & 1.50 & 17.3 \\
\hline 2 & $4000 \mathrm{~K}$ & $49.5 / 12.5 / 0 / 2.0$ & 1.49 & 0.49 & 0.86 & 10 & 0.61 & 1.50 & 17.3 \\
\hline \multirow[t]{2}{*}{3} & $6500 \mathrm{~K}$ & $50.0 / 12.5 / 0 / 2.0$ & 1.48 & 0.48 & 0.85 & 10 & 0.61 & 1.49 & 17.3 \\
\hline & & \multicolumn{8}{|c|}{ Class B $\left(\mathrm{f}_{1^{\prime}}=5.03 \%\right)$} \\
\hline 4 & $3000 \mathrm{~K}$ & $49.5 / 12.5 / 0 / 2.5$ & 1.50 & 0.51 & 0.85 & 10 & 0.60 & 1.50 & 17.3 \\
\hline 5 & $4000 \mathrm{~K}$ & $49.5 / 12.5 / 0 / 2.5$ & 1.50 & 0.51 & 0.85 & 10 & 0.60 & 1.50 & 17.3 \\
\hline \multirow[t]{2}{*}{6} & $6500 \mathrm{~K}$ & $49.0 / 12.5 / 0 / 2.5$ & 1.52 & 0.52 & 0.86 & 10 & 0.60 & 1.52 & 17.3 \\
\hline & & \multicolumn{8}{|c|}{ Class B $\left(\mathrm{f}_{1^{\prime}}=5.27 \%\right)$} \\
\hline 7 & $3000 \mathrm{~K}$ & $50.0 / 12.5 / 0 / 2.0$ & 1.48 & 0.48 & 0.85 & 10 & 0.61 & 1.49 & 17.3 \\
\hline 8 & $4000 \mathrm{~K}$ & $50.0 / 12.5 / 0 / 2.0$ & 1.48 & 0.48 & 0.85 & 10 & 0.61 & 1.49 & 17.3 \\
\hline \multirow[t]{2}{*}{9} & $6500 \mathrm{~K}$ & $50.0 / 12.5 / 0 / 2.0$ & 1.48 & 0.48 & 0.85 & 10 & 0.61 & 1.49 & 17.3 \\
\hline & & \multicolumn{8}{|c|}{ Class B $\left(f_{1^{\prime}}=5.62 \%\right)$} \\
\hline 10 & $3000 \mathrm{~K}$ & $49.5 / 12.5 / 0 / 2.0$ & 1.49 & 0.49 & 0.86 & 10 & 0.61 & 1.50 & 17.3 \\
\hline 11 & $4000 \mathrm{~K}$ & $50 / 12.5 / 0 / 2.0$ & 1.48 & 0.48 & 0.85 & 10 & 0.61 & 1.49 & 17.3 \\
\hline 12 & $6500 \mathrm{~K}$ & $50 / 12.5 / 0 / 1.5$ & 1.46 & 0.46 & 0.86 & 10 & 0.59 & 1.49 & 17.4 \\
\hline
\end{tabular}

For the cases of a 7.0 meter width road, one installed luminaire consumed $300 \mathrm{kWh} /$ year of electricity power, regardless of LED's CCT, in order to meet M4 class requirements. The number of installed luminaires per $\mathrm{km}$ of the road (the total power requirements for $1 \mathrm{~km}$ ) depended on luminaire's LPIC data. For lighting this road, the power requirement was $1725 \mathrm{~W} / \mathrm{km}$ for two cases shown in Table 8. In these two cases ( $4000 \mathrm{~K}$ and $6500 \mathrm{~K}$ LEDs), measurements were done by class $\mathrm{B}$ luxmeter (having $\mathrm{f}_{1}{ }^{\prime}$ equal to $5.03 \%$ ). In other cases, including a reference case, the power requirement was $1650 \mathrm{~W} / \mathrm{km}$. The 10.5 meter width road (M2 class) is lit by luminaires, which are consuming $780 \mathrm{kWh} /$ year electricity power each regardless of the LED CCT used. The number of luminaires which are required for meeting the lighting requirements depends on luminaire's LPIC data (see Table 9). The power requirement was $3900 \mathrm{~W} / \mathrm{km}$ for all luminaire's LPIC data including the reference project and projects based on luminaire's LPIC data measured with class B luxmeters (with f1' equal to 3.16\%; $5.03 \% ; 5.27 \%$ and $5.62 \%$ ) without applying SMCF to measurements.

Table 10 presents data for the $7.0 \mathrm{~m}$ wide road reflecting the change (increase) in electricity consumption $\Delta \mathrm{E}$ in MWh per kilometer per year (or in MWh per 10 and $100 \mathrm{~km}$ per year) for a lighting installation where LPIC data were measured correctly (with f1 error corrected properly by SMCF of luxmeter). The same data are shown in Table 11 for the 10.5 meter wide road.

Table 10. Changes in electricity consumption for a $7.0 \mathrm{~m}$ wide road.

\begin{tabular}{ccccc}
\hline CCT LED & $\begin{array}{c}\mathrm{E}_{\mathbf{1 k m}} \\
{[\mathbf{M W h} / \mathbf{k m}]}\end{array}$ & $\begin{array}{c}\Delta \mathrm{E}_{\mathbf{1 k m}} \\
{[\mathbf{M W h} / \mathbf{k m}]}\end{array}$ & $\begin{array}{c}\Delta \mathrm{E}_{\mathbf{1 0 k m}} \\
{[\mathbf{M W h} / \mathbf{1 0 k m}]}\end{array}$ & $\begin{array}{c}\Delta \mathrm{E}_{\mathbf{1 0 0 k m}} \\
{[\mathbf{M W h} / \mathbf{1 0 0 k m}]}\end{array}$ \\
\hline Reference & 6.6 & - & - & - \\
$4000 \mathrm{~K}$ & 6.6 & Class B (5.03\%) & 0.9 & 8.1 \\
$6500 \mathrm{~K}$ & 6.6 & 0 & 0.9 & 8.1 \\
\hline
\end{tabular}


Table 11. Changes in electricity consumption for a $7.0 \mathrm{~m}$ wide road.

\begin{tabular}{ccccc}
\hline CCT LED & $\begin{array}{c}\mathrm{E}_{\mathbf{1 k m}} \\
{[\mathbf{M W h} / \mathbf{k m}]}\end{array}$ & $\begin{array}{c}\Delta \mathrm{E}_{\mathbf{1 k m}} \\
{[\mathbf{M W h} / \mathbf{k m}]}\end{array}$ & $\begin{array}{c}\Delta \mathrm{E}_{\mathbf{1 0 k m}} \\
{[\mathbf{M W h} / \mathbf{1 0 k m}]}\end{array}$ & $\begin{array}{c}\Delta \mathrm{E}_{\mathbf{1 0 0 k m}} \\
{[\mathbf{M W h} / \mathbf{1 0 0 k m}]}\end{array}$ \\
\hline Reference & 15.6 & - & - & - \\
$6500 \mathrm{~K}$ & 15.6 & Class B $(5.03 \%)$ & 1.56 & 15.6 \\
\hline
\end{tabular}

\section{Discussion}

The impact on the results of the road lighting installation design without applying the SMCF correction factor when determining the LPIC of luminaires used was analyzed. The 12 prepared additional lighting designs were made for a typical 7.0 meter wide road (Table 8) and similarly, 12 lighting designs for a 10.5 meter wide road (Table 9). A reference design was prepared for each road. In the case of the 7.0 meter wide road, when the LPIC measurement was performed using a Class B luxmeter ( $\left(1^{\prime}=5.03 \%\right.$ - case $4-6$ in Table 8$)$, no impact on meeting quality lighting requirements was found. However, a negative impact on the energy efficacy of the two lighting installations was found, compared to the reference installation (case 5 and 6 in Table 8). The parameter De increased by $0.012 \mathrm{kWh} / \mathrm{m}^{2}$ per year, i.e., by $1.2 \%$ in relation to the De value in the reference installation. This increase can be explained by SMCF values above 1 (positive $\mathrm{f}_{1}{ }^{\prime}$ error values-Figure 7 ). In other cases (for the 7-meter wide road), without taking into account the SMCF factor when determining the LPIC (case 1-3 and 7-12), it was found that the lighting requirements were not met. The lighting requirements were not met for the mean luminance and were below the required level of $0.75 \mathrm{~cd} / \mathrm{m}^{2}$. When LEDs of CCT $3000 \mathrm{~K}$ and $4000 \mathrm{~K}$ were used in the luminaires (case 1, 2, 7, 8, 10, 11), the mean luminance was $0.74 \mathrm{~cd} / \mathrm{m}^{2}$. When using LEDs with CCT of $6500 \mathrm{~K}$ (case $3,9,12$ ) the mean luminance decreased to $0.73 \mathrm{~cd} / \mathrm{m}^{2}$ and was $0.02 \mathrm{~cd} / \mathrm{m}^{2}$ below the level required by the standards.

On the basis of the conducted analysis, it can be concluded that for a 7.0 meter wide road, without taking into account the SMCF when determining the luminaire's LPIC (applied in the lighting design), the lighting requirements were not met in nine cases (case 1-3 and 7-12 in Table 8). On the other hand, in 2 cases the De value increased (case 5,6), which negatively affected the energy efficacy of the designed lighting installations under analysis.

Analyzing the results of the tests carried out for the 10.5 meter wide road, it can be concluded that in the case of LPIC, without applying SMCF into measurement data (case 1 and 4-6 in Table 9), no impact on the lighting requirements was found. The negative impact on the energy efficacy of lighting installation was found only for case 6 in Table 9. The De value increased by $0.02[\mathrm{kWh} / \mathrm{m} 2]$ per year, i.e., by $1.3 \%$ in relation to the De value in the reference installation. This increase can be explained by fact that that the luxmeter's SMCF factor values was above 1 (i.e., creates positive $\mathrm{f}_{1^{\prime}}$ error values-Figure 7).

In other cases (for the 10.5 meter wide road) designed without taking into account the SMCF factor when determining the luminaire LPIC (in case 2, 3 and 7-12), it was found that the lighting requirements were not met. The lighting requirements were not met for the mean luminance values because they were below the required legal standard level of $1.50 \mathrm{~cd} / \mathrm{m}^{2}$. In cases 2 and 10 (Table 9), the mean luminance value was $1.49 \mathrm{~cd} / \mathrm{m}^{2}$, which is $0.01 \mathrm{~cd} / \mathrm{m}^{2}$ lower than the required by lighting standard. In the next 5 cases (no. 3, 7-9, 11) of lighting design, the average luminance value dropped to $1.48 \mathrm{~cd} / \mathrm{m}^{2}$, which is $0.02 \mathrm{~cd} / \mathrm{m}^{2}$ below the level required by the standards.

In one case of lighting design (case 12 in Table 9), the mean luminance dropped to $1.46 \mathrm{~cd} / \mathrm{m}^{2}$, which is $0.04 \mathrm{~cd} / \mathrm{m}^{2}$ below the level required by the standards.

To sum up, it was concluded that in 8 cases (no. 2,3 and 7-12 in Table 9) of lighting system designed for a 10.5 meter wide road, the failure to take the SMCF factor into account when determining the LPIC resulted in the failure to meet the lighting requirements. On the other hand, in case No. 6, the De index increased, which negatively affected the energy efficacy of the lighting system under analysis. 


\section{Conclusions}

In the literature to date, no studies have been presented on how luminaire photometric intensity curve measurements quality could influence results of street lighting design. There has also been no research on the study of the influence of failing to use the SMCF factor in LPIC measurements made with class B (class 2) luxmeters on the results of road lighting designs. The tests were conducted for a road width of $7.0 \mathrm{~m}$ and for a road width of $10.5 \mathrm{~m}$. The influence of inaccuracies in LPIC determination on the quality of road lighting design in relation to meeting the lighting requirements and the influence on energy efficacy of lighting were investigated. A comparative analysis of the results in individual lighting projects with the reference project made it possible to determine the impact of not taking the SMCF factor into account (correcting the CCT of the luminaire light source) on the results of the design calculations. It may seem that a small (several \% in value) error in LPIC measurements does not have a significant impact on the design results of road lighting installations. However, based on our research, it was found that even with such small values, its impact on lighting design results can be significant. In the cases presented in the article, a failure to take into account the SMCF factor when determining LPIC will result in shortening of the time in which those lighting installations will meet the lighting requirements-the lighting requirements of a given road will be met for a shorter time than for the exploitation time assumed for that project. The conducted research showed that failure to take the SMCF factor into account may lead, on one hand, to the failure to meet the lighting requirements and, on the other hand, to a reduction in the energy efficacy of the lighting installation. In the study, an analysis was carried out of 12 lighting designs for a 7.0 meter wide road and 12 designs for a 10.5 meter wide road. Out of the total of 24 lighting projects optimized for energy efficacy (but not including SMCF factor), nine projects for the 7.0 meter wide road and eight projects for the 10.5 meter wide road failed to meet the lighting requirements. In these cases, the designer, having erroneous data (which do not take the SMCF factor into account for a given CCT of the light source under investigation), would most often place lighting fixtures too wide apart. It results in the failure to meet the requirements of the average luminance of the road surface (marked in red in column 3, in Tables 7 and 8). This means that the new lighting installations would not meet the lighting requirements during their operation. This would create a potential threat to the safety and comfort of road users.

In the case of two lighting installations, for the road width of $7.0 \mathrm{~m}$ and one for the road width of $10.5 \mathrm{~m}$, the De value for energy efficacy has deteriorated. However, these changes are not high and could lead to an increase in electricity consumption over the course of a year of $8.1 \mathrm{MWh}$ (for a $7.0 \mathrm{~m}$ wide road) and 15.6 MWh (for a $10.5 \mathrm{~m}$ wide road) during the year, for $100 \mathrm{~km}$ of lighting installation. This should be considered as a negative phenomenon.

Taking into account the quoted research results, it is recommended that for LPIC tests of LED luminaires, even for Class B luxmeters, the LPIC is determined taking into account the SMCF correction factor. It is worth noting that if the SMCF correction factor is not applied with values greater than 1 (if required), the lighting installation may not meet the lighting requirements throughout its lifetime. On the other hand, if the correction factor of values lower than 1 (if required) is applied, the lighting installation may consume more electricity, so its energy efficacy may deteriorate. Therefore, it is very important to take the SMCF factor into account during photometric testing of luminaires.

Author Contributions: Conceptualization, I.F. and D.C.; Data curation, I.F. and D.C.; Methodology, I.F. and D.C.; Software, D.C. and I.F.; Writing-original draft, I.F. and D.C.; Writing-review \& editing, D.C. and I.F. All authors have read and agreed to the published version of the manuscript.

Funding: The author would like to express his gratitude to the Electrical Power Engineering Institute Warsaw University of Technology for funding and the possibility of publishing the results of the conducted research.

Acknowledgments: The author would like to express his gratitude to the Electrical Power Engineering Institute Warsaw University of Technology for funding and the possibility of publishing the results of the conducted research.

Conflicts of Interest: The author declare no conflict of interest. 


\section{References}

1. Güler, Ö.; Onaygil, S. The effect of luminance uniformity on visibility level in road lighting. Lighting Res. Tech. 2003, 35, 199-213. [CrossRef]

2. AbouElhamd, A.R.; Saraiji, R.A. Contrast Based Calculation Method for Roadway Lighting. Leukos 2018, 14, 193-211. [CrossRef]

3. Technical Report CIE 031:1976. Glare and Uniformity in Road Lighting Installations; CIE: Vienna, Austria, 1976.

4. Lin, Y.; Liu, Y.; Sun, Y.; Zhu, X.; Lai, J.; Heynderickx, I. Model predicting discomfort glare caused by LED road lights. Opt. Express 2014, 22, 18056-18071. [CrossRef] [PubMed]

5. Schmidt-Clausen, H.J.; Bindels, J.T.H. Assessment of discomfort glare in motor vehicle lighting. Lighting Res. Tech. 1974, 6, 79-88. [CrossRef]

6. Fotios, S.; Unwin, J.; Farrall, S. Road lighting and pedestrian reassurance after dark: A review. Lighting Res. Tech. 2015, 47, 449-469. [CrossRef]

7. Eloholma, M.; Ketomaki, J.; Orrevetelainen, P.; Halonen, L. Pedestrian Visibility in Road; Lighting Conditions. In Proceedings of the Illuminat 2003, 2nd International Lighting Conference, Cluj-Napoca, Romania, 26-28 September 2016.

8. Uttley, J.; Fotios, S. The effect of ambient light condition on road traffic collisions involving pedestrians on pedestrian crossings. Accid. Anal. Prev. 2017, 108, 189-200. [CrossRef]

9. Wanvik, P.O. Effects of road lighting: An analysis based on Dutch accident statistics 1987-2006. Accid. Anal. Prev. 2009, 41, 123-128. [CrossRef]

10. Technical Report CIE 115-2010. Lighting of Roads for Motor and Pedestrian Traffic; CIE: Vienna, Austria, 2010.

11. Standard EN-13201:2015. Road Lighting; CEN: Bruxelles, Belgium, 2015.

12. Standard ANSI/IESNA RP-8-00. Roadway Lighting; Illuminating Engineering Society of North America: New York, NY, USA, 2000.

13. Technical Report CIE 150-2017. Guide on the Limitation of the Effects of Obtrusive Light from Outdoor Lighting Installations; CIE: Vienna, Austria, 2017.

14. Czyżewski, D. Monitoring of the lighting conditions of a street illuminated with road lights equipped with LEDs. Prz. Elektrotech. 2010, 86, 170-172.

15. Ylinen, A.M.; Tähkämö, L.; Puolakka, M.; Halonen, L. Road Lighting Quality, Energy Efficiency, and Mesopic Design-LED Street Lighting Case Study. Leukos 2011, 8, 9-24. [CrossRef]

16. Jägerbrand, A.K. Synergies and Trade-Offs Between Sustainable Development and Energy Performance of Exterior Lighting. Energies 2020, 13, 2245. [CrossRef]

17. Green Paper. Lighting the Future Accelerating the Deployment of Innovative Lighting Technologies; European Commission: Brussels, Belgium, 2015.

18. Boyce, P.R.; Fotios, S.; Richards, M. Road lighting and energy saving. Lighting Res. Tech. 2009, 41, $245-260$. [CrossRef]

19. Peña-García, A. Towards Total Lighting: Expanding the Frontiers of Sustainable Development. Sustainability 2019, 11, 6943. [CrossRef]

20. Jägerbrand, A.K. LED (Light-Emitting Diode) Road Lighting in Practice: An Evaluation of Compliance with Regulations and Improvements for Further Energy Savings. Energies 2016, 9, 357. [CrossRef]

21. Commission Regulation (EC) No 245/2009; 24.3.2009, L 76/17; Official Journal of the European Union: Brussels, Belgium, 2009.

22. Lewin, I.; Box, P.; Start, R. An Economic Study of Three Light Sources for Roadway Lighting. Leukos 2005, 1, 73-80. [CrossRef]

23. Li, F.; Chen, Y.; Liu, Y.; Chen, D. Comparative in Situ Study of LEDs and HPS in Road Lighting. Leukos 2012, 8, 205-214. [CrossRef]

24. Tetri, E.; Chenani, S.B.; Räsänen, R.-S.; Baumgartner, H.; Vaaja, M.; Sierla, S.; Tähkämö, L.; Virtanen, J.-P.; Kurkela, M.; Ikonen, E.; et al. Tutorial: Road Lighting for Efficient and Safe Traffic Environments. Leukos 2017, 13, 223-241. [CrossRef]

25. Czyżewski, D. Luminance distribution of LED luminous surface. Prz. Elektrotech. 2009, 86, 166-169.

26. Czyżewski, D. Comparison of luminance distribution on the lighting surface of power LEDs. Photonics Lett. Pol. 2019, 11, 118-120. [CrossRef] 
27. Davidovic, M.; Djokic, L.; Cabarkapa, A.; Kostic, M. Warm white versus neutral white LED street lighting: Pedestrians' impressions. Lighting Res. Tech. 2019, 51, 1237-1248. [CrossRef]

28. Fryc, I.; Tabaka, P. Outdoor Areas Lighting with LEDs-the Competition Between Scotopic Efficacy and Light Pollution. Photonics Lett. Pol. 2019, 11, 75-77. [CrossRef]

29. Czyżewski, D. The street lighting luminaires with LEDs. Prz. Elektrotech. 2009, 85, 283-288.

30. Ge, A.; Shu, H.; Chen, D.; Cai, J.; Chen, J.; Zhu, L. Optical design of a road lighting luminaire using a chip-on-board LED array. Lighting Res. Tech. 2017, 49, 651-657. [CrossRef]

31. Nelson, M.A.; Anderson, B.P.; Cai, H. Selection Methods and Procedure for Evaluation of LED Roadway Luminaires. Leukos 2017, 13, 159-175. [CrossRef]

32. Güler, Ö. Determination of necessary criteria for calculations of road lighting based on visibility level. Ph.D. Thesis, Istanbul Technical University, Istanbul, Turkey, 2001.

33. Pachamanov, A.; Pachamanova, D. Optimization of the light distribution of luminaries for tunnel and street lighting. Engin. Opt. 2008, 40, 47-65. [CrossRef]

34. Lai, W.; Chen, W.M.; Liu, X.M.; Lei, X.H. Optimal design of light distribution of LED luminaries for road lighting. SPIE 2011, 8123, 81231P.

35. Technical Report CIE 121-1996. The Photometry \& Goniophotometry of Luminaires; CIE: Vienna, Austria, 1996.

36. Standard CEN-EN 13032-2:2017. Light and Lighting-Measurement and Presentation of Photometric Data of Lamps and Luminaires-Part 2: Presentation of Data for Indoor and Outdoor Work Places; European Committee for Standardization (CEN): Brussels, Belgium, 2017.

37. Gassmann, F.; Krueger, U.; Bergen, T.; Schmidt, F. Comparison of luminous intensity distributions. Lighting Res. Tech. 2017, 49, 62-83. [CrossRef]

38. Thorseth, A.; Lindén, J.; Dam-Hansen, C. A Comparison of Goniophotometric Measurement Facilities. In Proceedings of the CIE 2016 "Lighting Quality and Energy Efficiency", CIE—International Commission on Illumination, Vienna, Austria, 3-5 March 2016; pp. 547-554.

39. Standard ISO/CIE 19476:2014. Characterization of the Performance of Illuminance Meters and Luminance Meters; CIE: Vienna, Austria, 2014.

40. Technical Report CIE 231:2019. CIE Classiffication System of Illuminance and Luminance Meters; CIE: Vienna, Austria, 2019.

41. Krüger, U.; Blattner, P. Spectral Mismatch Correction Factor Estimation for White LED Spectra Based on the Photometer's f1' Value. CIE x038:2013. In Proceedings of the CIE Centenary Conference “Towards a New Century of Light", Paris, France, 15-16 April 2013.

42. Fryc, I. An analysis of the equation which is describing the spectral quality of photometer. Prz. Elektrotech. 2008, 84, 143-146.

43. Fryc, I.; Dimitrova-Grekow, T. An Automated System for Evaluation of the Quality of Light Sources. In Proceedings of the IEEE Lighting Conference of the Visegrad Countries Lumen V4, Karpacz, Poland, 13-16 September 2016.

44. Fryc, I. Errors of spectral correction caused by the diffusing element of the photometric meter head during illuminence measurement. In Proceedings of the SPIE 2001, 4517, Lightmetry: Metrology, Spectroscopy, and Testing Techniques Using Light, Pułtusk, Poland, 10 August 2001. [CrossRef]

45. Technical Report CIE 154-2003. The Maintenance of Outdoor Lighting Systems; CIE: Vienna, Austria, 2003.

46. Technical Report CIE 239:2020. Goniospectroradiometry of Optical Radiation Sources; CIE: Vienna, Austria, 2020.

47. Jakubowski, P.; Fryc, I. Metrological requirements for measurements of circadian radiation. Opt. Appl. 2018, 48, 697-704. [CrossRef]

48. Kuusk, J.; Ansko, I.; Bialek, A.; Vendt, R.; Fox, N. Implication of Illumination Beam Geometry on Stray Light and Bandpass Characteristics of Diode Array Spectrometer. IEEE J. Sel. Top. Appl. Earth Obs. Remote. Sens. 2018, 11, 2925-2932. [CrossRef]

49. Jakubowski, P.; Kowalska, J.; Supronowicz, R.; Fryc, I. The Influence of Spectral Measurements Uncertainty of Fluorescent Lamps on Calculated Value of their Relative Melanopic Weighted Irradiance and Colour Quality Parameters. In Proceedings of the 7th Lighting Conference of the Visegrad Countries: LUMEN V4, Třebíč, Czech Republic, 18-20 September 2018.

50. Moore, J.R.; Stott, P.; Davees, I.F.; Halstead, M.B.; Large, F.E. The effect of measurement uncertainty on the colour rendering indices of fluorescent lamps. Light Res. Technol. 1973, 5, 17-28. [CrossRef] 
51. Shaw, M.; Goodman, T. Array-based goniospectroradiometer for measurement of spectral radiant intensity and spectral total flux of light sources. Appl. Opt. 2008, 47, 2637-2647. [CrossRef]

52. Schinke, C.; Franke, M.; Bothe, K.; Nevas, S. Implementation and uncertainty evaluation of spectral stray light correction by Zong's method. Appl. Opt. 2019, 58, 9998-10009. [CrossRef] [PubMed]

53. Barlier-Salsi, A. Stray light correction on array spectroradiometers for optical radiation risk assessment in the work place. J. Radiol. Prot. 2014, 34, 915-930. [CrossRef] [PubMed]

54. Zong, Y.; Brown, S.W.; Johnson, B.C.; Lykke, K.R.; Ohno, Y. Simple spectral stray light correction method for array spectroradiometers. Appl. Opt. 2006, 45, 1111-1119. [CrossRef] [PubMed]

55. Fryc, I.; Czyzewski, D. Chosen parameters of CCD type spectroradiometers. Prz. Elektrotech. 2009, 8, $276-277$.

56. Fryc, I. Spectral Correction of Detector Used in Illuminance Measurements. In Proceedings of the Volume 3820, 11th Slovak-Czech-Polish Optical Conference on Wave and Quantum Aspects of Contemporary Optics, Stara Lesna, Slovakia, 21-25 September 1998.

57. Slominski, S. Typical Causes of Errors during Measuring Luminance Distributions in Relation to Glare Calculations. In Proceedings of the 7th Lighting Conference of the Visegrad Countries: LUMEN V4, Třebíč, Czech Republic, 18-20 September 2018.

(C) 2020 by the authors. Licensee MDPI, Basel, Switzerland. This article is an open access article distributed under the terms and conditions of the Creative Commons Attribution (CC BY) license (http://creativecommons.org/licenses/by/4.0/). 